\title{
Penggunaan Alat Bantu Pembelajaran untuk Meningkatkan Gerak Dasar Lompat Tinggi Gaya Straddle pada Siswa Kelas VI Sekolah Dasar
}

\author{
Basri \\ Sekolah Dasar Negeri 020-UPTD Pendidikan Samarinda Ilir
}

\begin{tabular}{|c|c|}
\hline INFO ARTIKEL & ABSTRAK \\
\hline Riwayat Artikel: & $\begin{array}{l}\text { Abstract: This study aims to determine the increase in the basic motion of the high jump } \\
\text { straddle force using learning aids. The method used is a two-cycle class action research. }\end{array}$ \\
\hline Diterima: 12-01-2019 & Each cycle is carried out in the form of a mixed assessment process consisting of four \\
\hline Disetujui: 16-04-2019 & $\begin{array}{l}\text { stages, namely planning, implementing, observing, and reflecting. The target of the } \\
\text { research is the students of class VI semester } 11 \text { of elementary school } 020 \text { Samarinda Ilir. }\end{array}$ \\
\hline Kata kunci: & $\begin{array}{l}\text { Based on the results of the analysis there is an increase in the average value of students } \\
\text { completeness from the pre-cycle (67.7), the first cycle (71.5) and the second (77.2). In }\end{array}$ \\
\hline $\begin{array}{l}\text { high jump; } \\
\text { straddle style; }\end{array}$ & $\begin{array}{l}\text { addition, based on observations students look more interested so they can improve the } \\
\text { learning process of high jump practice. }\end{array}$ \\
\hline
\end{tabular}

elementary student;

lompat tinggi;

gaya straddle;

siswa $S D$

\begin{abstract}
Abstrak: Penelitian ini bertujuan untuk mengetahui peningkatan gerak dasar lompat tinggi gaya straddle menggunakan alat bantu pembelajaran. Metode yang digunakan merupakan penelitian tindakan kelas sebanyak dua siklus. Setiap siklus dilaksanakan dalam wujud proses pengkajian berdaur yang terdiri atas empat tahap, yakni perencanaan, pelaksanaan, observasi, dan refleksi. Sasaran penelitian adalah siswa kelas VI semester 11 Sekolah Dasar Negeri 020 Samarinda Ilir. Berdasarkan hasil analisis terdapat peningkatan nilai rata-rata ketuntasan siswa dari pra siklus (67.7), siklus pertama (71.5) dan kedua yakni (77.2). Selain itu, berdasarkan observasi siswa terlihat lebih tertarik sehingga dapat meningkatkan proses pembelajaran praktik lompat tinggi.
\end{abstract}

\author{
Alamat Korespondensi: \\ Basri \\ Sekolah Dasar Negeri 020 \\ UPTD. Pendidikan Samarinda Ilir \\ E-mail: ayikgugun@gmail.com
}

Pendidikan jasmani, olahraga, dan kesehatan merupakan media pendorong terhadap keterampilan motorik, kemampuan fisik, pengetahuan, dan penalaran serta pembiasan pola hidup sehat (Indrawati, 2013). Dalam pendidikan, penjasorkes tidak dapat dipandang sebagai pelajaran yang hanya dianggap sebagai main-main. Seiring dengan kemajuan di dunia pendidikan, muncul banyak metode pembelajaran yang dapat menjadi salah satu alternatif dari perrnasalahan pembelajaran yang ada saat ini, sekaligus dapat digunakan untuk menciptakan suksesnya tujuan pembelajaran (Sani, 2013) (Ramadan, 2017). Meskipun begitu, metode pembelajaran belum banyak diterapkan di sekolah karena guru belum banyak yang mempelajari metode-metode pembelajaran. Dalam kasus penjasorkes, memberikan pembelajaran atletik yang menarik, praktis dan diminati siswa adalah tugas seorang guru (Febrianti, 2013). Oleh karena itu, guru harus mampu menyesuaikan kebutuhan yang berhubungan dengan siswa dan materi pembelajaran tersebut. Guru juga harus mampu menerapkan pendekatan, model, metode dan strategi yang sesuai dengan materi pembelajaran yang akan disampaikan (Saragih, 2008) (Suprihatin, 2015).

Hasil observasi dan wawancara dengan salah satu guru mata pelajaran pedidikan jasmani di Sekolah Dasar Negeri 020 Jalan Damai Kelurahan Sidodamai Samarinda Ilir Tahun Ajaran 2014/2015 menunjukkan bahwa para siswa di SD tersebut memiliki kemampuan menengah ke bawah, disamping beberapa siswa memiliki intelegensi di atas rata-rata. Dalam sebuah observasi kelas, dapat diketahui bahwa siswa-siswi di kelas VI memiliki minat dan motivasi yang kurang terhadap pelajaran pendidikan jasmani. Hal tersebut, tampak beberapa siswa yang mengobrol dengan temannya sendiri, mengantuk, malas-malasan dalam mengerjakan instruksi yang diberikan oleh guru. Sebagian besar siswa mengeluh dan merasa tidak mampu mengerjakan tugas yang diberikan. Berdasarkan permasalahan tersebut perlu adanya solusi dalam pelaksanaan pembelajaran umum yang dihadapi guru dalam menyampaikan materi, khususnya gerak dasar lompat tinggi gaya straddle. Salah satu solusi yang memungkinkan adalah penggunaan alat bantu pembelajaran untuk menciptakan suasana pembelajaran yang menarik dan berimplikasi pada hasil pembelajaran yang positif. 
Lompat tinggi gaya Straddle merupakan salah satu nomor lompat dalam cabang olahraga atletik. Lompat tinggi merupakan suatu bentuk gerakan melompat, melayang, dan mendarat setinggi-tingginya. Gerakan-gerakan dalam lompat tinggi tersebut barus dilakukan secara balk dan harmonis tidak diputus-putus pelaksanaannya agar diperoleh lompatan setinggi-tingginya. Gaya straddle adalah gaya dengan lompatan perut berhadapan dengan mistar. Manfaat latihan ini adalah mampu melakukan lompatan dengan optimal. Dalam pelaksanaanya terdapat empat komponen utama pada lompat tinggi ini, yaitu (1) langkah lari awalan, (2) teknik tolakan kaki, (3) bentuk gerakan saat melayang, dan (4) teknik mendarat.

Sebagai bagian dari materi sub-pokok mata pelajaran penjasorkes, tujuan dari pembelajaran Lompat Tinggi Gaya Straddle tidak terlepas dari tujuan pendidikan jasmani secara umum. Adapun tujuan penjas menurut Depdiknas (2006) yaitu (1) mengembangkan dan meningkatkan keterampilan gerak, (2) meletakkan landasan karakter moral yang kuat melalui intemalisasi nilai-nilai yang terkandung didalamnya (sportivitas, kejujuran, disiplin, tanggung jawab, kerja sama, percaya diri, dan demokratis), dan (3) Memahami konsep aktivitas jasmani dan olahraga sebagai informasi untuk mencapai pertumbuhan fisik yang sempurna, pola hidup sehat dan kebugaran, terampil, serta memiliki sikap yang positif.

Alat bantu pembelajaran merupakan alat-alat yang digunakan oleh pendidik dalam menyampaikan materi pembelajaran (Soekidjo, 2003). Alat bantu ini lebih sering disebut alat peraga karena berfungsi untuk membantu dan mempraktekan sesuatu dalam proses pendidikan pengajaran (Falahudin, 2014). Dengan kata lain, alat peraga ini dimaksudkan untuk mengerahkan indera sebanyak mungkin suatu objek sehingga mempermudah persepsi (Hartati, 2010). Manfaat alat bantu pembelajaran menurut Soekidjo (2003) diantaranya: (1) Menimbulkan rninat sasaran pendidikan, (2) Mencapai sasaran yang lebih banyak, (3) Membatu mengatasi hambatan bahasa, (4) Merangsang sasaran pendidikan untuk melaksanakan pesan-pesan kesehatan, (5) Membantu sasaran pendidikan untuk belajar lebih banyak dan cepat, (6) Merangsang sasaran pendidikan untuk meneruskan pesan-pesan yang diterima kepada orang lain, (7) Mempermudah peyampaian bahan pendidikan/informasi oleh para pendidik pelaku pendidikan, dan (8) Mempermudah penerimaan informasi oleh sasaran pendidikan, seperti diuraikan di atas bahwa pengetahuan yang ada pada seseorang diterima melalui indera.

Alat bantu pembelajaran yang baik mempunyai tujuan pendidikan untuk mengubah pengetahuan, pengertian, pendapat dan konsep-konsep, mengubah sikap dan persepsi, menanamkan tingkah laku/kebiasaan yang baru (Waluyanto, 2006) (Nurseto, 2011). Selain itu, alat bantu harus efisien dalam penggunaanya, dalam waktu yang singkat dapat mencakup isi yang luas dan tempat yang diperlukan tidak terlalu luas. Penempatan alat bantu perlu diperhatikan ketepatannya agar dapat diamati dengan baik oleh siswa. Efektif artinya memberikan hasil guna yang tinggi ditinjau dari segi pesannya dan kepentingan siswa yang sedang belajar sedangkan yang dimaksud dengan komunikatif ialah bahwa media tersebut mudah untuk dimengerti maksudnya, sehingga membuat siswa mejadi lebih mudah dalam menerima pembelajaran yang diberikan oleh guru.

Pembelajaran lompat tinggi gaya straddle dengan menggunakan alat bantu pada siswa sekolah dasar hendaknya disesuaikan dengan karakteristik siswa. Pada umumnya, usia sekolah dasar cenderung lebih suka bentuk pembelajaran yang sifatnya menyenangkan. Nuansa gembira atau menyenangkan adalah faktor penting dalam pembelajaran pendidikan jasmani di sekolah dasar. Oleh karena itu, dalam membelajarkan Lompat Tinggi Gaya Straddle hendaknya berupa gerakan-gerakan yang menyenangkan atau dengan modifikasi alat bantu yang mengarah pada karakteristik gerakan Lompat Tinggi Gaya Straddle. Bentuk-bentuk Pembelajaran Lompat Tinggi Gaya Straddle dengan Menggunakan Alat Bantu Pembelajaran menurut Djumidar (2001) terdapat bermacam-macam modifikasi alat bantu yang mengarah pada pembelajaran Lompat Tinggi Gaya Straddle sebagai berikut.

Pertama, pembelajaran awalan Lompat Tinggi Gaya Straddle menggunakan alat bantu bilah. Pembelajaran lompat jauh menggunakan bilah, menipakan bentuk belajar yang pelaksanaanya dilakukan dengan melompati bilah menggunakan dua kaki dengan jarak antar bilah bertahap, dimulai dari tinggi $0,5 \mathrm{~m}, 1 \mathrm{~m}, 1,5 \mathrm{~m}$. Pembelajaran menggunakan alat bantu berupa bilah mempunyai kelebihan berupa: (a) Dapat meningkatkan power otot tungkai, dan (b) Gerakanya dapat dilakukan dengan cepat dan penuh tanaga karena beban tubuh diangkat lebih ringan.

Kedua, model permainan melewati beberapa peti kayu, tujuan dari pembelajaran ini untuk meningkatkan koordinasi gerakan lari dan lompat serta untuk membuat siswa merasa senang dan termotivasi untuk melaksanakan gerakan. Alat yang digunakan: 4 buah peti kayu, cara melaksanakan permainannya: siswa melakukan lari dan lompat melewati peti kayu yang tersusun sedemikian rupa, dipasang dengan jarak antar peti kayu 1,50 m, jumlah peti kayu yang dipasang 4 buah peti kayu /baris. Model permainannya dapat dilakukan secara individu atau grup dan dapat pula dilakukan dengan sistem kompetisi atau perlombaan dan dilaksanakan secara berkelompok. masing-masing siswa harus melakukan lari melewati peti kayu sebanyak $3-5$ kali, setelah itu istirahat $1-2$ menit, selanjutnya dapat dilakukan permainan seperti yang telah dilakukan tadi. Adapun kelebihan dari pembelajaran dengan alat bantu peti kayu: (a) Dapat meningkatkan pewer otot tungkai, (b) Siswa menjadi lebih termotivasi karena adanya rintangan kotak kardus sehingga memacu untuk saling berkompetisi antar siswa Gerakanya menyerupai gerakan menumpu pada Lompat Tinggi Gaya Straddle.

Ketiga, Model permainan koordinasi, tujuan pembelajaran untuk mencapai gerakan yang harmonis dan untuk mendapatkan gerakan yang otomatis, artinya gerakannya dapat dilakukan dengan kontinyu tidak terputus-putus. Untuk pembelajaran Lompat Tinggi Gaya Straddle menggunakan alat bantu peti kayu permainan ini dapat melatih koordinasi antara awalan, tolakan, saat di udara dan pendaratan. Alat yang digunakan: $4-5$ buah peti kayu, cara melakukan permainanya hampir sama dengan permainan yang pertama, 
perbedaannya pada permainan ini peti kayu yang dipasang menjadi empat baris dan dipasang lima banjar jarak antar banjar 1,5 m. Model permainannya siswa lari melewati kardus secara bersama-sama empat orang/seri, dapat dilakukan secara berulang-ulang. Alasan mengapa menggunakan kardus sebagai rintangan adalah alat harus sesuai dengan tingkat kesulitan anak atau siswa, yaitu tinggi rendahnya agar diciptakan yang lebih mudah untuk melompatinya, supaya terhindar dan sentuhan yang dapat membahayakan. Peti kayu merupakan alat yang tidak membahayakan dan bersifat lembut, apabila bagian tungkai atau kaki siswa bersentuhan tidak akan merasa sakit. Peti kayu juga bersifat ringan apabila tersentuh akan cepat bergeser dan terjatuh hal ini tidak akan membahayakan siswa apabila melompatinya. Oleh sebab itu, penelitian ini menggunakan peti kayu sebagai alat bantu untuk pendekatan permainan dalam pembelajaran Lompat Tinggi Gaya Straddle.

Pembelajaran melayang di udara Lompat Tinggi Gaya Straddle dengan menggunakan alat bantu lingkaran yang digantung. Dalam pembelajaran melayang di udara siswa melakukan pembelajaran meraih lingkaran yang digantung. Ketinggian lingkaran dapat disesuaikan dengan tingkat kemampuan siswa dari rendah sampai tinggi. Pembelajaran mendarat lompat tinggi gaya straddle dengan menggunakan alat bantu ban bekas. Pembelajaran mendarat Lompat Tinggi Gaya Straddle menggunakan alat bantu ban bekas, merupakan bentuk belajar yang pelaksanaanya dilakukan dengan berlari melewati ban atau berada di tengah lingkaran dengan jarak yang telah ditentukan. Pembelajaran ini bertujuan untuk mengatur langkah pada saat awalan dalam lompat tinggi gaya straddle sehingga pada waktu melakukan tolakan tepat di atas garis batas tumpuan.

\section{METODE}

Penelitian menggunakan metode penelitian tindakan kelas dengan waktu pelaksanaan tiga bulan. Penentuan pelaksanan penelitian mengacu pada kalender pendidikan SDN 020 dan mempertimbangkan siklus yang memerlukan proses pembelajaran yang efektif dan efisien. Subjek penelitian ini adalah Peneliti sebagai Kepala Sekolah Dasar Negeri 020 Samarinda Ilir. dan Subyek dari penelitian ini adalah siswa kelas VI.A semester 12 Sekolah Dasar Negeri 020 Jalan Damai Kelurahan Sidodamai Samarinda Ilir Tahun Ajaran 2014/2015 Samarinda Ilir dengan jumlah siswa putri 18 orang dan putra 19 orang.

Tahap Pelaksanaan Penelitian terbagi menjadi dua siklus dan setiap siklus terdapat empat tahap yaitu perencanaan, tindakan, observasi, dan refleksi. Tujuan pada siklus I yaitu melaksanakan pembelajaran sesuai dengan rencana pembelajaran dan mengamati kekurangan yang terjadi. Selanjutnya pada siklus II bertujuan memperbaiki kesalahan terkait hasil refleksi pada siklus pertama sehingga meningkatkan kemampuan dan ketrampilan dasar lompat jauh gaya jongkok, melalui pendekatan metode pembelajaran dengan alat bantu (ban bekas, kardus, bilah). Kondisi akhir melalui penggunaan alat bantu (ban bekas, kardus, dan bilah) dapat meningkatkan kesegaran jasmani siswa (siswa lebih bersemangat dan prestasi belajar meningkat) serta partisipasi siswa dalam mengikuti pembelajaran meningkat kondisi awal guru kurang kreatif dan inovatif dalam proses pembelajaran penjas. Tahap penelitian yang terdiri dari dua siklus ini mengadopsi rancangan pelaksanaan penelitian tindakan kelas oleh Arikunto (2006) dapat dilihat pada gambar 1.

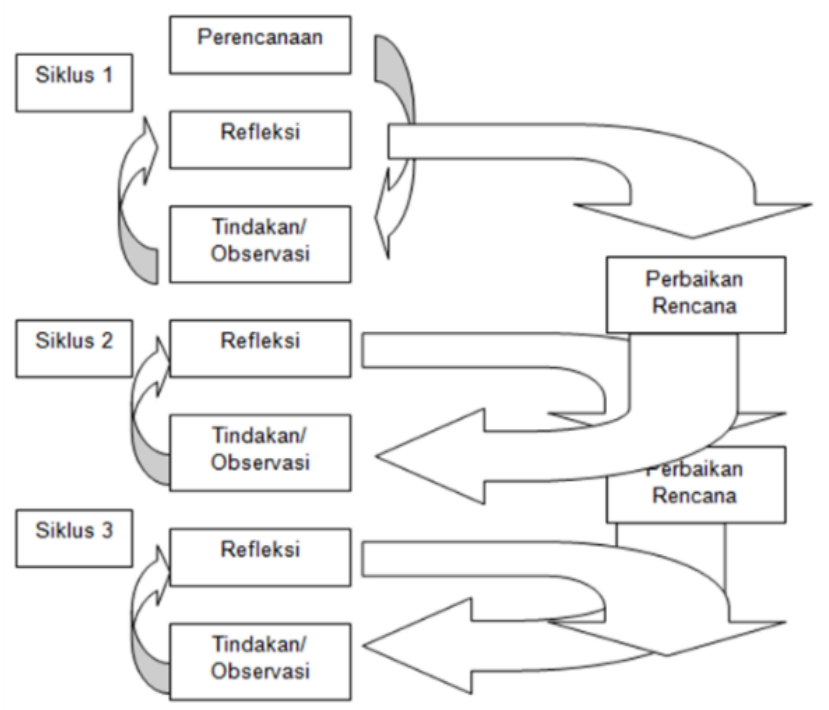

Gambar 1. Bagan Rancangan Pelaksanaan PTK Model Spiral (Arikunto, 2006) 
Berdasarkan rancangan pada gambar 1, setiap siklus memiliki empat tahapan utama, yakni perencanaan, pelaksanaan, observasi, dan refleksi. Adapun kegiatan-kegiatan yang dilaksanakan setiap tahapan siklus dapat dilihat pada tabel 1.

Tabel 1. Uraian Kegiatan Setiap Tahapan Siklus

\begin{tabular}{|c|c|c|}
\hline Tahapan & Siklus I & Siklus II \\
\hline Perencanaan & $\begin{array}{ll}\text { 1. } & \text { Analisis kurikulum } \\
\text { 2. } & \text { Membuat RPP } \\
\text { 3. } & \text { Menyusun Instrumen } \\
\text { 4. } & \text { Menyiapkan alat bantu pembelajaran } \\
\text { 5. } & \text { Menyusun evaluasi } \\
\end{array}$ & $\begin{array}{l}\text { Tindakakan dikaitkan dengan hasil yang dicapai pada siklus } \\
\text { pertama sebagai upaya perbaikan. Sebagai tambahan disusun } \\
\text { juga lembar kegiatan siswa dan tes formatif untuk } \\
\text { mengumpulkan data hasil kegiatan siswa. }\end{array}$ \\
\hline Pelaksanaan & $\begin{array}{l}\text { Melaksanakan sekenario pembelajaran yang telah } \\
\text { direncanakan, tahap ini dilakukan dengan tahap observasi } \\
\text { terhadap dampak tindakan. }\end{array}$ & $\begin{array}{l}\text { Melaksanakan sekenario pembelajaran yang telah diperbaiki } \\
\text { sesuai dengan evaluasi pada siklus pertama }\end{array}$ \\
\hline Observasi & $\begin{array}{l}\text { Pengamatan terhadap penerapan metode pembelajaran } \\
\text { langsung pendidikan jasmani metode pendekatan bermain } \\
\text { dengan alat modifikasi yang diterapkan terhadap proses } \\
\text { pembelajaran penjas. }\end{array}$ & $\begin{array}{l}\text { Hasil pengamatan yang dilakukan dengan menggunakan } \\
\text { lembar kerja pengamatan melihat ketika siswa mengikuti } \\
\text { proses pembelajaran. }\end{array}$ \\
\hline Refleksi & $\begin{array}{l}\text { menganalisis hasil observasi dan interpretasi sehingga } \\
\text { diperoleh kesimpulan apa saja yang perlu diperbaiki dan apa } \\
\text { saja yang perlu dipertahankan }\end{array}$ & $\begin{array}{l}\text { menganalisis hasil observasi dan interpretasi untuk dijadikan } \\
\text { hasil penelitian selama dua siklus }\end{array}$ \\
\hline
\end{tabular}

Setelah rancangan kegiatan ditetapkan, langkah selanjutnya adalah pelaksanaan pengumpulan data. Teknik pengumpulan data yang digunakan dalam penelitian adalah pengamatan, kegiatan anak melakukan percobaan yang dijadikan sampel penelitian (Moleong, 2004). Sumber data dalam penelitian tindakan kelas ini adalah sebagai berikut: (a) Data tentang lompat tinggi gaya straddle diperoleh dari siswa, (b) Data tentang proses pembelajaran lompat jauh diperoleh dari kejadian-kejadian dalam pelaksanaan pembelajaran, (c) Data tentang kegiatan pembelajaran lompat tinggi gaya straddle dari kolaborator dalam pelaksanaan kegiatan pembelajaran, (d) Guru, sebagai kolaborator untuk melihat tingkat keberhasilan penggunaan alat bantu pembelajaran, dan (e) Dokumentasi atau arsip berupa kurikulum, skenario pembelajaran, silabus, buku penelitian, dan buku referensi mengajar.

Uji validitas data yang digunakan dalam penelitian ini adalah triangulasi data. Teknik triangulasi merupakan teknik uji validitas dengan memanfaatkan sarana di luar data itu sebagai perbandingan terhadap data-data yang telah diperoleh (Bachri, 2010). Teknik trianggulasi data yang digunakan adalah sebagai berikut: (a) Trianggulasi sumber yaitu data yang diperoleh dengan informan atau nara sumber yang lain baik dan siswa, guru lain atau pihak-pihak yang lain (kepala sekolah, rekan guru, orangtua/wali murid), (b) Trianggulasi metode yaitu mengumpulkan data dengan metode yang berbeda agar hasilnya lebih mantap (hasil observasi dan tes) sehingga didapat hasil yang akurat mengenai subjek.

Teknik observasi guru yang dilakukan dengan mengamati kondisi proses belajar mengajar yang berlangsung observasi ini menggunakan tabel observasi untuk mengetahui keaktifan guru. Teknik observasi siswa yang dilakukan dengan cara mengamati kondisi proses belajar mengajar yang berlangsung Observasi ini menggunakan tabel observasi untuk mengetahui keaktifan Siswa. Dalam lembar observasi berisi pernyataan dan tanggapan pengamat dan lembar observasi siswa berisi tentang kegiatan siswa dalam mengikuti proses pembelajaran diamati dan di ben tanggapan oleh peneliti sesuai dengan keadaan siswa saat pembelajaran.

\section{Teknik Analisis Data}

Data yang dikumpulkan pada setiap kegiatan observasi dari pelaksanaan siklus PTK. dianalisis secara deskriptif kualitatif. Teknik analisis tersebut dilakukan karena sebagian besar data yang dikumpulkan berupa uraian deskriptif tentang perkembangan proses pembelajaran pada sub pokok bahasan lompat jauh. Teknik analisis ini dilakukan dalam tiga komponen, meliputi reduksi data, penyajian data, dan penarikan kesimpulan. Pertama, reduksi data, yaitu meliputi penyeleksian data melalui seleksi yang ketat, melalui ringkasan atau uraian singkat, menggolongkannya dalam satu pola yang lebih luas. Kedua, penyajian data, dilakukan dalam rangka mengorganisasikan data yang merupakan penyusunan informasi secara sistematik dari hasil reduksi data. Ketiga, penarikan kesimpulan atau verifikasi merupakan upaya pencarian makna data, mencatat keteraturan dan penggolongan data. Data yang terkumpul disajikan secara sistematis dan bermakna. 


\section{HASIL DAN PEMBAHASAN}

Sebelum melaksanakan proses penelitian tindakan kelas, terlebih dahulu dilakukan kegiatan survei awal untuk mengetahui keadaan nyata yang ada di lapangan. Hasil kegiatan survei awal tersebut adalah sebagai berikut.

Pertama, siswa yang mengikuti materi pelajaran penjas khususnya atletik adalah 37 siswa yang terdiri atas 19 siswa putra dan 18 siswa putri. Dilihat dari proses pembelajaran atletik khususnya materi lompat tinggi gaya straddle, dapat dikatakan proses pembelajaran dalam kategori kurang berhasil.

Kedua, siswa kurang rnenuliki perhatian dan motivasi dalam pembelajaran lompat tinggi gaya straddle, sebab guru kurang memiliki motode mengajar yang tepat dalam materi lompat tinggi gaya straddle dalam jtunlah siswa yang terlampau banyak.

Ketiga, dari basil wawancara yang dilakukan diperoleh informasi bahwa siswa cenderung sulit diatur saat materi lompat tinggi gaya straddle berlangsung. Hal ini dapat dibuktikan oleh peneliti saat melakukan pengamatan secara langsung di lapangan. Saat mengikuti materi lompat jauh gaya jongkok, siswa menunjukkan sikap seenaknya sendiri, tidak memperhatikan penjelasan guru, tidak memperhatikan pelajaran dengan sepenuhnya, ada yang berbicara dengan teman, bahkan ada yang bermain sendiri dengan temannya.

Keempat, guru kurang bisa menghandel keadaan kelas, sebab jumlah siswa yang terlampau banyak dengan situasi tempat belajar yang cukup ramai, menjadikan situasi belajar menjadi kurang dapat diatur dengan baik. Sehingga tingkat kemampuan siswa dalam lompat tinggi gaya straddle tidak dapat maksimal.

Kelima, guru kesulitan menemukan model pembelajaran lompat tinggi gaya straddle yang baik dan benar. Seringkali contoh yang disampaikan oleh guru melalui peragaan langsung, kurang dapat dicermati oleh siswa secara baik, sebab siswa kurang dapat melihat kondisi gerakan lompat jauh gaya jongkok yang diperagakan oleh guru, balk karena kurangnya antusiasme siswa atau contoh gerakan kurang dapat dipahami oleh siswa. Sebelum melakukan pelaksanaan tindakan maka peneliti dan guru melakukan pengambilan data awal penelitian. Ini dimaksudkan untuk mengetahui kondisi awal keadaan kelas pada materi gerak dasar lompat tinggi gaya straddle pada siswa kelas VI.B Semester 11 Sekolah Dasar Negeri 020 Samarinda Ilir Tahun Ajaran 2014/2015.

Berdasarkan hasil deskripsi rekapitulasi data awal sebelum diberikan tindakan didapatkan mayoritas siswa belum menunjukan hasil belajar yang baik, dengan persentase ketuntasan belajar 43,24\% (16 siswa). Melalui diskripsi data awal yang telah diperoleh tersebut masing masing aspek menunjukkan kriteria keberhasilan pembelajaran yang kurang. Pada langkah observasi dan interpretasi ini dilakukan oleh peneliti dan guru kolaborasi saat proses pembelajaran berlangsung. Adapun hasil observasi menyimpulkan bahwa siswa terlihat senang dengan pembelajaran melalui pendekatan bermain menggunakan alat bantu pembelajaran yang diberikan. Hal ini terlihat dan sikap siswa yang begitu semangat dan antusias saat proses pembelajaran.

Setelah itu dilakukan analisis dan refleksi atas keberhasilan dan kegagalan yang terjadi pada pertemuan pertama. Keberhasilan guru/siswa: Pembelajaran melalui pendekatan bermain menggunakan alat bantu pembelajaran dapat memotivasi siswa untuk belajar dan mengulangi lagi pelajaran tersebut. Pendekatan bermain menggunakan alat bantu pembelajaran lebih menantang siswa untuk belajar melakukan gerakan lompat jauh, karena model pembelajarannya bersifat kompetisi dan bermain sehingga siswa tidak merasa bosan dalam mengikuti pembelajaran dan merasa ada tantangan tersendiri untuk mengikuti pembelajaran. Sedangkan kendala yang dihadapi guru/siswa: Melalui pendekatan bermain menggunakan alat bantu yang terdapat unsur-unsur kompetisi membuat siswa harus mau bekerjasama dalam kelompoknya, kendala yang dihadapi dalam hal ini adalah ada seorang siswa yang tidak bisa mengikuti pembelajaran lompat tinggi gaya straddle karena kakinya sedang sakit akibat terkilir dan ada siswa lain yang tidak masuk karena sakit. Kendala lain yaitu jenis permainan yang menggunakan peti kayu mengganggu siswa karena ada siswa yang tidak bisa melompati peti kayu sehingga siswa jatuh. Dengan adanya hal itu siswa ada yang mengeluh karma sering membetulkan peti kayu. Untuk mendorong siswa agar lebih semangat dalam melakukan pembelajaran serta menghilangkan rasa bosan tersebut maka sebaiknya peneliti memberikan reward kepada siswa, seperti memberikan pujian. Sehingga siswa mampu termotivasi dan juga melupakan rasa bosan dan malas saat membetulkan kardus tersebut setelah larut dalam permainan yang diberikan.

Setelah itu dilakukan rencana perbaikan berdasarkan basil analisis dalam pembelajaran pada pertemuan pertama antara lain: (a) Agar siswa tidak salah dalam melakukan setiap gerakan pada kegiatan pembelajaran tersebut, maka peneliti memberikan penjelasan cara bermain dengan benar dalam pembelajaran lompat tinggi gaya straddle. (b) Siswa yang dirasa kurang berhasil pada pertemuan pertama akan diberikan perhatian yang lebih intensif pada pertemuan berikutnya. Peneliti harus tetap memberikan pemahaman dan motivasi pembelajaran yang berorientasi pada pendekatan permainan.

Setelah tindakan setiap siklus dilakukan dan diperbaiki pada tahap refleksi didapatkan deskripsi data akhir siklus I dan II Hasil Gerak Dasar lompat tinggi gaya straddle pada Siswa kelas VI-B Semester 11 Sekolah Dasar Negeri 020 Samarinda Ilir Tahun Ajaran 2014/2015. Berdasarkan hasil tersebut terdapat peningkatan ketuntasan dari pra siklus, siklus I dan II. Data ketuntasan dapat dilihat pada tabel 2 . 
Tabel 2. Data Ketuntasan Siklus I dan II

\begin{tabular}{|c|c|c|c|c|c|c|c|c|}
\hline \multirow{2}{*}{ Rentang Nilai } & \multirow{2}{*}{ Kriteria } & \multirow{2}{*}{ Keterangan } & \multicolumn{3}{|c|}{ Jumlah Siswa } & \multicolumn{3}{|c|}{ Persentase } \\
\hline & & & Pra Siklus & Siklus I & Siklus II & Pra Siklus & Siklus I & Siklus II \\
\hline$>85$ & Baik Sekali & Tuntas & 0 & 0 & 12 & $0 \%$ & 0 & $32.43 \%$ \\
\hline $75-84$ & Baik & Tuntas & 3 & 9 & 15 & $8.11 \%$ & $24.32 \%$ & $40.54 \%$ \\
\hline $65-74$ & Cukup & Tuntas & 14 & 17 & 10 & $37.83 \%$ & 45.955 & $27.03 \%$ \\
\hline $60-64$ & Kurang & Tidak Tuntas & 12 & 0 & 0 & $32.43 \%$ & $0 \%$ & $0 \%$ \\
\hline$<60$ & Kurang Sekali & Tidak Tuntas & 8 & 11 & 0 & $21.63 \%$ & $29.73 \%$ & $0 \%$ \\
\hline
\end{tabular}

Berdasarkan data tersebut, keberhasilan siswa hasil tes pada siklus II menunjukkan bahwa hasil gerak dasar lompat tinggi gaya straddle siswa meningkat dari pra siklus, siklus I dan II. Pendekatan bermain menggunakan alat bantu pembelajaran memberikan banyak pencerahan dalam metode pembelajaran dan lebih menantang siswa untuk melakukan latihan lompat jauh. Berdasarkan hasil pelaksanaan tindakan pada siklus I dan II perbandingan hasil tindakan antar siklus dapat disimpulkan bahwa terjadi peningkatan hasil gerak dasar lompat tinggi gaya straddle.

Hasil penelitian dan hasil perbandingan antar siklus di atas dapat disimpulkan bahwa model pembelajaran alat bantu pembelajaran dapat meningkatkan hasil gerak dasar lompat tinggi gaya straddle siswa hal ini terbukti dari penerapan model pembelajaran alat bantu pada materi pembelajaran lompat tinggi gaya straddle yang mengalami peningkatan di tiap tindakan yang diberikan. Terlebih dari persentase hasil pembelajaran lompat tinggi gaya straddle pada siklus II yang telah memenuhi target dari yang direncanakan yaitu $78.13 \%$ dengan jumlah siswa tuntas adalah 25 siswa dari jumlah keseluruhan 37 siswa.

Dari peningkatan hasil gerak dasar lompat tinggi gaya straddle di atas dapat disimpulkan bahwa model pembelajaran alat bantu dalam pelaksanaan pembelajaran lompat tinggi gaya straddle dapat memberikan pencerahan kepada guru sebagai alternatif dalam memilih model-model pembelajaran khususnya materi pembelajaran lompat tinggi gaya straddle guna meningkatkan hasil gerak dasar siswa dan juga sebagai bentuk usaha guru dalam menyampaikan materi pembelajaran agar siswa dapat berperan aktif selama mengikuti proses pembelajaran sehingga tujuan dari pembelajaran tersebut dapat tercapai secara maksimal.

Penelitian terkait tentang penggunaan alat bantu atau media untuk mendukung pembelajaran Penjasorkes telah dilakukan sebelumnya. Penelitian oleh (Bajuri, 2016) menyatakan bahwa peningkatan hasil belajar lompat Tinggi Gaya Straddle menngunakan alat bantu pembelajaran. Penelitian Citrasari (2014) menyatakan keterampilan senam ritmik anak kelompok B1 TK Negeri Pembina Sukoharjo dapat ditingkatkan melalui media simpai. Hal tersebut dapat dilihat dari peningkatan dari pra siklus, siklus I dan II. Penelitian lain menyatakan bahwa melalui pendekatan pembelajaran bermain tali pada materi senam lantai meroda dapat meningkatkan keterampilan senam meroda siswa kelas VIIIA MTs Ma'arif NU Kemiri (Wuryantoro \& Muktiani 2011). Selain itu, penelitian oleh Hanief (2016) menyatakan bahwa media alat bantu tali lebih baik pengaruhnya terhadap peningkatan keterampilan back handspring dibanding dengan bantuan teman.

\section{SIMPULAN}

Berdasarkan hasil evaluasi dan observasi ketuntasan hasil gerak dasar lompat tinggi gaya straddle. Tes statistik pra siklus jumlah 2505 rerata 67,7. Siklus I jumlah 2645 rerata 71,5 dan siklus II Jumlah 2855 rerata 77,2. Implikasi penelitian ini juga memberikan deskripsi yang jelas bahwa melalui pendekatan bermain menggunakan alat bantu dalam pembelajaran lompat jauh gaya straddle dapat meningkatkan hasil belajar siswa sehingga penelitian ini dapat digunakan sebagai suatu pertimbangan bagi guru yang ingin menggunakan media pengajaran dengan pendekatan bermain menggunakan alat bantu pembelajaran.

Bagi guru bidang studi Pendidikan Jasmani dan Olahraga, hasil penelitian ini dapat digunakan sebagai suatu alternatif dalam melaksanakan proses pembelajaran Penjas khususnya yang berkaitan dengan peningkatan hasil belajar lompat jauh gaya jongkok yang efektif dan menarik yang membuat siswa lebih aktif serta menghapus persepsi siswa mengenai pembelajaran Penjas yang membosankan menjadi pembelajaran yang menyenangkan. Apalagi bagi guru yang memiliki kemampuan lebih kreatif dalam membuat model-model pembelajaran yang lebih banyak. Ia dapat menyalurkan kemampuannya tersebut dan memanfaatkan fasilitas yang tersedia di sekolah dalam upaya meningkatkan kinerja sebagai seorang pendidik yang profesional dan inovatif.

Pemberian tindakan dari siklus I dan II memberikan deskripsi bahwa terdapat kekurangan yang terjadi selama proses pembelajaran berlangsung. Namun, kekurangan-kekurangan tersebut dapat diatasi pada pelaksanaan tindakan pada siklus-siklus berikutnya. Pelaksanaaan tindakan yang kemudian dilakukan refleksi terhadap proses pembelajaran dapat dideskripsikan terdapatnya peningkatan kualitas pembelajaran Pendidikan Jasmani dan peningkatan hasil belajar siswa. Dari segi proses pembelajaran Pendidikan Jasmani, penerapan model pembelajaran melalui pendekatan bermain rnenggunakan alat bantu dapat merangsang aspek motorik siswa. Dalam hal ini siswa dituntut untuk aktif dalam pembelajaran Penjas yang nantinya dapat bermanfaat untuk mengembangkan kebugaran jasmani, mengembangkan kerjasama, mengembangkan keterampilan dan mengembangkan sikap kompetitif yang kesemuanya ini sangat penting dalam pendidikan jasmani. 


\section{DAFTAR RUJUKAN}

Arikunto, S. (2006). Prosedur Penelitian Suatu Pendekatan Praktik. Jakarta: Rineka Cipta.

Bachri, B. S. (2010). Meyakinkan Validitas Data melalui Triangulasi pada Penelitian Kualitatif. Jurnal Teknologi Pendidikan, 10(1), $46-62$.

Bajuri, P. E. (2016). Penerapan Alat Bantu Pembelajaran untuk Meningkatkan Hasil Belajar Lompat Tinggi Gaya Straddle. Jurnal SPORTIF, 2(2).

Citrasari, Y. (2014). Upaya Meningkatkan Keterampilan Senam Ritmik melalui Media Simpai Pada Anak Kelompok B1 Di TK Negeri Pembina Sukoharjo Tahun Ajaran 2013/2014. Disertasi tidak diterbitkan. Universitas Muhammadiyah Surakarta, Surakarta.

Depdiknas. (2006). "Permendiknas Nomor 24 Tahun 2006 tentang Pelaksanaan Permendiknas Nomor 22 Tahun 2006 tentang Standar Isi untuk Pendidikan Dasar dan Menengah

Djumidar, D. (2001). Dasar-Dasar Atletik. Jakarta: Universitas Terbuka.

Falahudin, I. (2014). Pemanfaatan Media dalam Pembelajaran. Jurnal Lingkar Widyaiswara, 1(4), 104-117.

Febrianti, R. (2013). Pengembangan Materi Atletik melalui Permainan Atletik Three in One untuk Siswa SD Kelas V. Journal of Physical Education and Sports, 2(1).

Hanief, Y. N. (2016, December). Perbedaan Pengaruh Pengunaan Alat Bantu Tali dan Bantuan Teman terhadap Peningkatan Keterampilan Back Handspring. In Prosiding Seminar Nasional Pendidikan Jasmani Pascasarjana UM (pp. 192-202).

Hartati, B. (2010). Pengembangan Alat Peraga Gaya Gesek untuk Meningkatkan Keterampilan Berpikir Kritis Siswa SMA. Jurnal Pendidikan Fisika Indonesia, 6(2).

Indrawati, R. (2013). Peningkatan perilaku disiplin siswa melaluipemberian reward dan punishment dalam pembelajaran penjasorkes pada siswa kelas XII IPS 1 SMA Negeri 1 Lamongan. Jurnal Pendidikan Olahraga dan Kesehatan, 1(2).

Moleong, L. J. (2004). Metodologi Penelitian Kualitatif. Bandung: Remaja Rosdakarya.

Nurseto, T. (2011). Membuat Media Pembelajaran yang Menarik. Jurnal Ekonomi dan Pendidikan, 8(1).

Ramadan, G. (2017). Pengaruh metode pembelajaran dan motivasi belajar terhadap hasil belajar passing sepakbola. JUARA: Jurnal Olahraga, 2(1), 1-10.

Sani, R. A. (2013). Inovasi Pembelajaran. Jakarta: Bumi Aksara.

Saragih, A. H. (2008). Kompetensi Minimal Seorang Guru dalam Mengajar. Jurnal Tabularasa, 5(1), 23—34.

Soekidjo, N. (2003). Pengembangan Sumber Daya Manusia. Jakarta: Rineka Cipta.

Suprihatin, S. (2015). Upaya Guru dalam Meningkatkan Motivasi Belajar Siswa. Jurnal Pendidikan Ekonomi UM Metro, 3(1), 7382.

Waluyanto, H. D. (2006). Komik sebagai Media Komunikasi Visual Pembelajaran. Nirmana, 7(1).

Wuryantoro, K., \& Muktiani, N. R. (2011). Meningkatkan Keterampilan Senam Meroda melalui Permainan Tali pada Siswa Kelas VIII A MTs Ma’arif NU. Jurnal Pendidikan Jasmani Indonesia, 8(2). 